\title{
Capture efficiency and size selectivity of sampling gears targeting red-swamp crayfish in several freshwater habitats
}

\author{
J.-M. Paillisson ${ }^{(1,2)}$, A. Soudieux ${ }^{(3)}$, J.-P. Damien ${ }^{(3)}$ \\ Received December 7, 2010 \\ Revised February 17, 2011 \\ Accepted March 1, 2011
}

\section{ABSTRACT}

Key-words: effort, length-frequency distribution, Procambarus clarkii, sampling method, trapping catch-per-unit

The ecological importance of the red-swamp crayfish (Procambarus clarkii) in the functioning of freshwater aquatic ecosystems is becoming more evident. It is important to know the limitations of sampling methods targeting this species, because accurate determination of population characteristics is required for predicting the ecological success of $P$. clarkii and its potential impacts on invaded ecosystems. In the current study, we addressed the question of trap efficiency by comparing population structure provided by eight trap devices (varying in number and position of entrances, mesh size, trap size and construction materials) in three habitats (a pond, a reed bed and a grassland) in a French marsh in spring 2010. Based on a large collection of $P$. clarkii $(n=2091,272$ and 213 respectively in the pond, reed bed and grassland habitats), we found that semicylindrical traps made from $5.5 \mathrm{~mm}$ mesh galvanized steel wire (SCG) were the most efficient in terms of catch probability $(96.7-100 \%$ compared to $15.7-82.8 \%$ depending on trap types and habitats) and catchper-unit effort (CPUE: $15.3,6.0$ and 5.1 crayfish.trap ${ }^{-1} \cdot 24 \mathrm{~h}^{-1}$ compared to $0.2-4.4,2.9$ and 1.7 crayfish.trap ${ }^{-1} \cdot 24 \mathrm{~h}^{-1}$ by the other types of fishing gear in the pond, reed bed and grassland respectively). The SCG trap was also the most effective for sampling all size classes, especially small individuals (carapace length $\leqslant 30 \mathrm{~mm}$ ). Sex ratio was balanced in all cases. SCG could be considered as appropriate trapping gear to likely give more realistic information about $P$. clarkii population characteristics than many other trap types. Further investigation is needed to assess the catching effort required for ultimately proposing a standardised sampling method in a large range of habitats.

\section{RÉSUMÉ}

Efficacité de capture et sélectivité des tailles d'écrevisses rouges de Louisiane échantillonnées par différents engins de pêche dans plusieurs habitats dulçaquicoles

Mots-clés : L'importance écologique de l'écrevisse rouge de Louisiane (Procambarus clarkii) capture par unité dans le fonctionnement des écosystèmes aquatiques dulçaquicoles est de plus en d'effort, nelles est essentielle pour prédire le succès écologique de $P$. clarkii et ses impacts

(1) UMR 6553 ECOBIO CNRS/Université de Rennes 1, Campus de Beaulieu, avenue du Général Leclerc, 35042 Rennes Cedex, France, jean-marc.paillisson@univ-rennes1.fr

(2) UMR 985 ESE INRA/Agrocampus Ouest, 65 route de Saint-Brieuc, 35042 Rennes Cedex, France

(3) Parc naturel régional de Brière, 177 île de Fédrun, 44720 Saint-Joachim, France 
distribution de fréquence de tailles, Procambarus clarkii, méthode d'échantillonnage, piégeage potentiels sur les écosystèmes envahis, il est important de connaître les limites des méthodes d'échantillonnage. Dans la présente étude, nous traitons de la question de l'efficacité de piégeage en comparant les caractéristiques populationnelles fournies par huit types de pièges (variant selon le nombre et la position des entrées, la taille de maille, la taille du piège et les matériaux de construction) dans trois habitats (un plan d'eau, une roselière et une prairie inondée) d'un marais en France, et cela au printemps 2010. Sur la base d'un large échantillonnage d'écrevisses ( $n=2091,272$ et 213 individus capturés respectivement dans le plan d'eau, la roselière et la prairie inondée), nous avons mis en évidence que les pièges semi-cylindriques en acier galvanisé et de maille de 5,5 mm (SCG) étaient les plus efficaces en termes de probabilité de capture (96,7-100\% comparés aux $15,7-82,8 \%$ obtenus dans les autres pièges et dans les trois habitats) et de capture par unité d'effort (CPUE : 15,3; 6,0 et 5,1 écrevisses.piège ${ }^{-1} \cdot 24 \mathrm{~h}^{-1}$ contre $0,2-4,4 ; 2,9$ et 1,7 écrevisses. piège ${ }^{-1} \cdot 24 \mathrm{~h}^{-1}$ trouvées dans les autres pièges respectivement dans le plan d'eau, la roselière et la prairie inondée). Les pièges SCG étaient également les plus efficaces pour échantillonner toutes les classes de taille, et particulièrement les petites écrevisses (longueur de carapace $\leqslant 30 \mathrm{~mm}$ ). Le sexe ratio était équilibré dans tous les cas. Les pièges SCG pourraient être considérés comme un engin de pêche approprié pour fournir des informations probablement plus réalistes sur les caractéristiques de populations de $P$. clarkii que de nombreux autres types de piège. Des études supplémentaires sont nécessaires afin d'évaluer l'effort d'échantillonnage requis pour finalement proposer une méthode d'échantillonnage standardisée dans une large gamme d'habitats.

\section{INTRODUCTION}

The current spread of some non-indigenous crayfish species across the world and the rapid establishment of self-sustaining populations are accused of being responsible for drastic ecological damage and the decline of biodiversity in invaded freshwater ecosystems (e.g. Gherardi (2007) for a review). A paradigm of invasive crayfish is the red swamp crayfish Procambarus clarkii, a species native to north-eastern Mexico and south-central USA (Hobbs, 1988), which is today the most cosmopolitan crayfish found in the wild (Gherardi, 2006). $P$. clarkii has the profile of a very successful invader, including particularly a wide plasticity of life cycle and a high dispersal ability that allow the species to invade a large diversity of ecosystems (e.g. Guttiérrez-Yurrita et al., 1999; Geiger et al., 2005). Although the ecological effects of $P$. clarkii in aquatic ecosystems is becoming more evident (e.g. Rodríguez et al., 2003; Ilhéu et al., 2007; Correia and Anastácio, 2008; Matsuzaki et al., 2009), there is a need to better understand and predict the ecological success of the species, and therefore its impact on ecosystems. For this, an investigation of the environmental factors influencing the population characteristics of $P$. clarkii is a good starting point and will be helpful in the development of ways to control the species (Alcorlo et al., 2008; Anastácio et al., 2009).

Trapping is likely to be the most useful method for sampling active $P$. clarkii (Huner, 1988) since the species inhabits aquatic ecosystems which usually have turbid waters thus limiting the efficiency of techniques such as manual search, night viewing and electro-fishing. However, the sampling methods used have many limitations and no really standardized method has been proposed to permit rigorous comparisons of life history events between populations. Instead of this, $P$. clarkii has been sampled using a variety of equipment, sometimes within a single study, and in some cases, no description of gear characteristics was given (Table I, see also Pfister and Romaire (1983)). Nevertheless, there are a number of instances where it has been shown that traps are size- and sex-selective, favouring the collection of larger crayfish (e.g. Qvenild and Skurdal, 1989; Edsman and Söderbäck, 1999). Mesh size especially is a determinant of catch rates and size at which crayfish are captured (e.g. Qvenild and Skurdal, 1989). Trap efficiency also depends on other trap characteristics including construction material, number and size of entrances, type of bait and time of trap exposure (e.g. Huner, 1988; 
Table I

Sampling gear used to investigate population structure and dynamics of P. clarkii in a series of habitats.

Tableau I

Engins utilisés pour étudier la structure et la dynamique de population de $P$. clarkii dans une gamme d'habitats.

\begin{tabular}{|lll|}
\hline Sampling gears & Habitats & References \\
\hline Baited trap (6 mm mesh size) & rice field, pond, ditch & Alcorlo et al. (2008) \\
Dip net (3 mm mesh size) & marsh & Anastácio et al. (2009) \\
Dip net (no description) & pond, lake & Chiesa et al. (2006) \\
Dip net (3 mm mesh size) & rice field, stream, reservoir Correia (1995) \\
Fyke net (no description) & lake & Dörr et al. (2006) \\
Baited traps (no description) & pond & Frutiger et al. (1999) \\
Baited traps (2 mm mesh size) & ditch & Gherardi et al. (1999) \\
Unbaited traps (6-8 mm mesh size) & lake & \\
Cylindrical traps (10 mm mesh size) & stream & Guerra and Niño (1995) \\
Crayfish disk & & \\
Baited traps (19 mm mesh size) & pond & Huner and Paret (1995) \\
Baited cylindrical traps (partial description) & river & Ligas (2008) \\
Baited traps (no description) & wetland & Scalici and Gherardi (2007) \\
Baited cylindrical traps (8 mm mesh size) & wetland & Scalici et al. (2010) \\
\hline
\end{tabular}

Fjälling, 1995; Huner and Paret, 1995). So many errors can exist when evaluating several aspects of population dynamics. Moreover, environmental factors such as substrate and vegetation can affect gear performance, and this additional factor needs to be addressed to understand the life histories of $P$. clarkii in different habitats.

In this context, the goal of this study was to compare the efficiency of different trap types used to capture $P$. clarkii in order to identify a fishing gear that would provide accurate or, at least, more realistic parameters of population structures than many other trap types commonly used in a large range of habitats. More specifically, we explored catch probability, catch rates and size- and sex-selectivity associated with different traps (two to seven) in three typical temporarily flooded habitats of a large freshwater marsh.

\section{MATERIALS AND METHODS}

\section{> STUDY AREA}

The study was carried out in the Brière marsh $\left(47^{\circ} 22^{\prime} \mathrm{N}, 02^{\circ} 11^{\prime} \mathrm{W}\right)$, a 6842 -ha freshwater marsh located in north-western France. It is composed of a network of permanently flooded canals (144 km covering $206 \mathrm{ha}$ ) surrounded by a heterogeneous patchwork of temporary habitats (6636 ha) including grazed grasslands, reed beds and water ponds used for hunting (Cucherousset et al., 2006, 2007). Seasonally inundated habitats generally flood in winter and dry out progressively in late spring and summer as a result of the rainfall regime and water level management. P. clarkii was introduced into the Brière marsh in the 1980 s as a result of individuals escaping from a crayfish farm located in the vicinity of the marsh. It has spread rapidly throughout the marsh since its introduction, and can now be found in high densities all over the area (Paillisson et al., unpublished data). The present study was carried out in April 2010 in three temporarily flooded habitats of the marsh: a pond, a grassland area and a reed bed. The surface of the pond was $715 \mathrm{~m}^{2}$ and the mean water level was $60 \mathrm{~cm}$ during the study, with a mean vegetation cover of $57.3 \pm 0.1 \%(95 \% \mathrm{Cl})$ and a peat substrate. The other two habitats had lower water levels: $30.4 \pm 1.3 \mathrm{~cm}$ and $21.5 \pm 1.4 \mathrm{~cm}$ during the study for the 5.76-ha reed bed and the 1.93-ha grassland respectively. The reed bed was densely vegetated with many Phragmites australis and Carex spp. stands whereas the vegetation cover in the grassland was low and composed of Poaceae with sparse patches of submerged plants (Ranunculus spp. and Callitriche spp.). The substrate of these two habitats mainly consisted 
of peat. During the study, water conductivity ranged from 739 to $805 \mu \mathrm{S} \cdot \mathrm{cm}^{-1}$, and in the pond, the reed bed and the grassland, pH was 8.15, 7.02 and 6.85 and the concentration of dissolved oxygen was $5.9,4.3$ and $3.2 \mathrm{mg} \cdot \mathrm{L}^{-1}$ respectively. Mean daily water temperature was $15.2 \pm 0.4{ }^{\circ} \mathrm{C}(95 \% \mathrm{Cl})$ in the pond throughout the survey (temperature was recorded every hour using an automatic sensor, StowAway TidBit, Onset Computer Corporation, Bourne, MA, USA). Water temperature was higher than values inhibiting crayfish activity $\left(<10^{\circ} \mathrm{C}\right.$, in Huner and Barr (1991)).

\section{> TRAP TYPES AND CRAYFISH SAMPLING}

Many types of traps are used to catch crayfish (Westman, 1991; Holdich, 2002). The main differences between traps include construction materials, mesh sizes, physical dimensions, number of entrance funnels and the presence or absence of bait (e.g. Huner and Barr, 1991; Fjälling, 1995). Two main types of traps were used in the present study: cylindrical traps with a side entrance (one or two entrances) and traps with the entrance on the top. All trap characteristics are described in Table II. We used seven trap types to catch $P$. clarkii in the pond, but only two trap types in the other sites given the low water level. Field operations were carried out in 2010, during two periods of 3-4 days in the pond (13-16 April and 23-30 April) and on 27 April in the reed bed and the grassland. It consisted of setting alternately one trap of the seven trap devices, containing dog food, directly into the bottom at 1.5-2.0 m intervals along the shoreline of the pond. This procedure was repeated ten times, totalling 70 operating traps at each date. By doing this, the shoreline of the pond was totally sampled. 27-31 unbaited traps were set haphazardly at 5-10 $\mathrm{m}$ intervals in the reed bed and the grassland (see details in Table II). All traps were numbered and left in the water for $24 \mathrm{~h}$ at each site to reduce the possible bias in catch efficiency that can arise from the presence of crayfish already trapped. Captured crayfish were counted, placed in identified bags and frozen at $-20{ }^{\circ} \mathrm{C}$ immediately after collection for further analysis. In the laboratory, the carapace length (CL) from the tip of rostrum to the end of the carapace of each individual was measured with a digital caliper to the nearest $0.01 \mathrm{~mm}$. Sex was verified by the presence of developed gonopodia occurring in individuals with a CL longer than 13-16 mm. Data from the two sampling periods in the pond were combined for analysis. For each trap type and habitat, catch efficiency was expressed as 1) catch probability, defined as the number of traps with crayfish (or more exactly the number of $24 \mathrm{~h}$-catch periods) divided by the total number of traps (in \%); and 2) catchper-unit-effort (CPUE) which was calculated as the number of crayfish caught per trap per $24 \mathrm{~h}$ period (crayfish trap $^{-1} \cdot 24 \mathrm{~h}^{-1}$ ). Sex ratio was calculated as the ratio between the number of females and the total number of sexed individuals for each trap type and habitat.

\section{> DATA ANALYSIS}

Since the aim of this study was not to compare $P$. clarkii captures between habitats, no analysis was performed using habitats as factor. Fisher's exact test was used to compare catch probability and also sex ratio between pairs of trap types in each separate habitat. Prior to statistical analyses, CPUE data were transformed logarithmically $\left(\log _{10}(x+1)\right)$ due to the right-skewed distribution of the data. Analysis of variance (one-way ANOVA) was used to test for differences in mean CPUE between trap types (trap type factor) in each habitat. When tests were significant, multiple comparisons were performed using the post hoc Tukey HSD procedure. We used the FISAT II software package (version 1.2.2 FAO-ICLARM) and applied modal progression analysis to CL-frequency distribution data to classify crayfish into different size classes. A likelihood-ratio chi-square test was used to compare the proportion of all size classes between trap types in each habitat. All statistical analyses were performed using STATISTICA (version 6.0), and 0.05 was taken as significance level. Values are the mean $\pm 95 \%$ confidence interval $(95 \% \mathrm{Cl})$. 


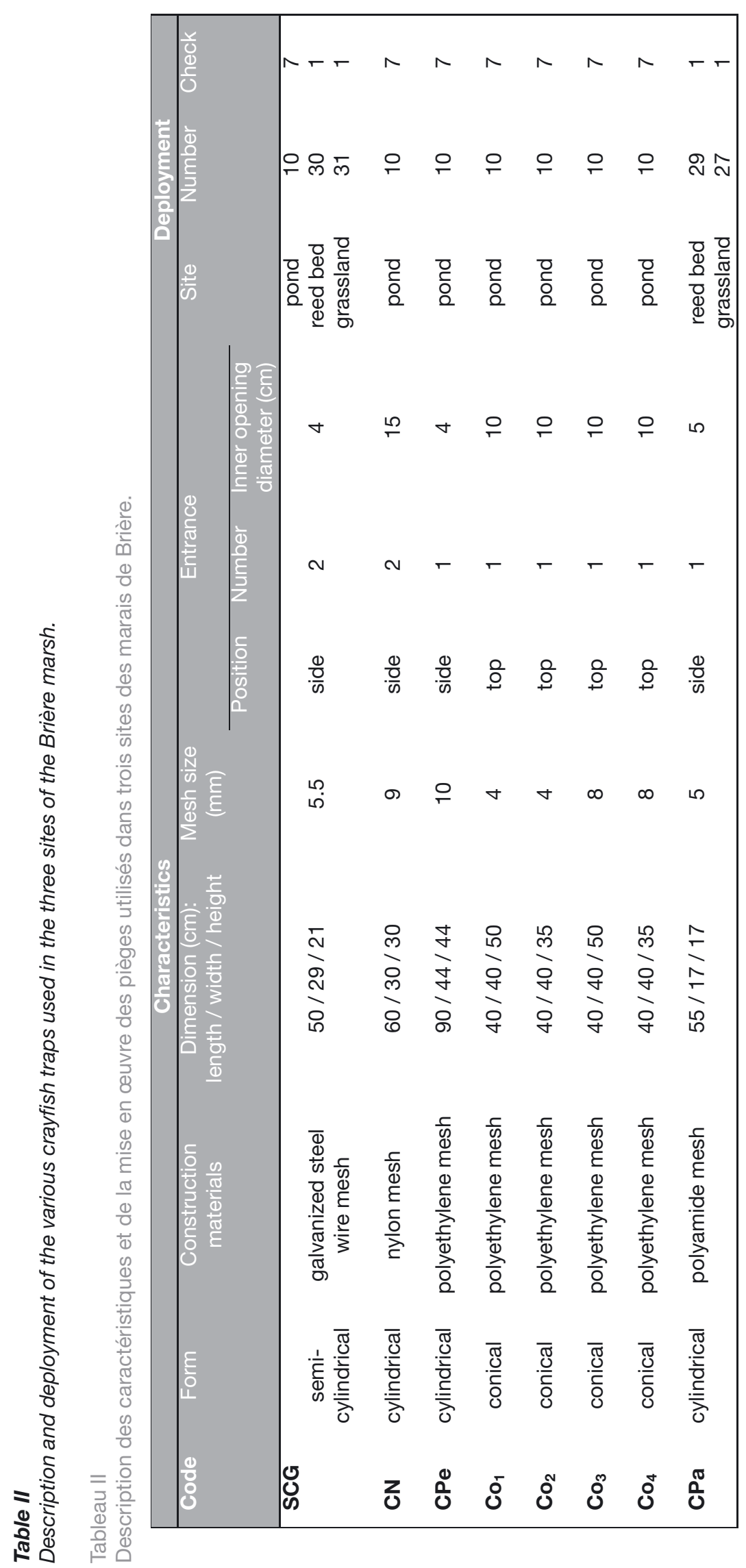




\section{Table III}

Crayfish captures (catch probability, CPUE, total number and sex ratio) from various trap types in three habitats of the Brière marsh. The number of sexed individuals is reported in brackets. See Table II for a detailed description of trap designs and deployment.

\section{Tableau III}

Captures en écrevisses (probabilité de capture, CPUE, total et sexe-ratio) selon différents types de piège dans trois habitats des marais de Brière. Le nombre d'individus sexés est indiqué entre parenthèses. Voir le tableau II pour une description détaillée des caractéristiques des pièges et de leur mise en œuvre.

\begin{tabular}{|c|c|c|c|c|c|}
\hline \multirow[t]{4}{*}{ Trap types } & \multicolumn{5}{|c|}{ Crayfish captures } \\
\hline & \multirow{3}{*}{$\begin{array}{c}\text { Catch } \\
\text { probability (\%) }\end{array}$} & \multicolumn{3}{|c|}{ CPUE } & \multirow[t]{3}{*}{ Sex ratio } \\
\hline & & Mean & Range & Total & \\
\hline & & \multicolumn{3}{|c|}{ (number.trap ${ }^{-1} \cdot 24 \mathrm{~h}^{-1}$ ) } & \\
\hline \multicolumn{6}{|l|}{ Pond } \\
\hline SCG & 100.0 & 15.3 & $1-48$ & 1074 & $0.49(956)$ \\
\hline CN & 82.8 & 4.4 & $0-17$ & 307 & $0.44(294)$ \\
\hline $\mathrm{CPe}$ & 71.4 & 4.2 & $0-14$ & 293 & $0.54(272)$ \\
\hline $\mathrm{Co}_{1}$ & 27.1 & 0.4 & $0-5$ & 28 & - \\
\hline $\mathrm{Co}_{2}$ & 80.0 & 3.5 & $0-16$ & 246 & $0.51(243)$ \\
\hline $\mathrm{Co}_{3}$ & 15.7 & 0.2 & $0-2$ & 14 & - \\
\hline $\mathrm{Co}_{4}$ & 61.4 & 1.8 & $0-9$ & 129 & $0.51(128)$ \\
\hline \multicolumn{6}{|l|}{ Reed bed } \\
\hline SCG & 96.9 & 6.0 & $0-21$ & 193 & $0.58(154)$ \\
\hline $\mathrm{CPa}$ & 72.4 & 2.9 & $0-14$ & 79 & $0.46(70)$ \\
\hline \multicolumn{6}{|l|}{ Grassland } \\
\hline SCG & 96.7 & 5.1 & $0-23$ & 164 & $0.49(131)$ \\
\hline $\mathrm{CPa}$ & 77.7 & 1.7 & $0-7$ & 49 & $0.44(41)$ \\
\hline
\end{tabular}

-: too few individuals to calculate a sex ratio.

\section{RESULTS}

\section{$>$ TRAP EFFICIENCY}

In total, 2091, 272 and 213 P. clarkii were captured respectively in the pond, reed bed and grassland during the study. There were large differences in catch probability using the seven trap types in the pond. Catch probabilities ranged from 15.7 to $100 \%$ (Table III) and pairwise comparisons (Fisher's exact test) resulted in the following pattern: SCG $>\left[\left(\mathrm{Co}_{2}=\mathrm{CN}\right) \geqslant\right.$ $\left.\left(\mathrm{CPe}=\mathrm{Co}_{4}\right)\right]>\left(\mathrm{Co}_{1}=\mathrm{Co}_{3}\right)$. SCG was also the most efficient in capturing crayfish in the other two habitats (Table III, Fisher's exact test, $p<0.05$ ). Catch probability was close to $100 \%$ in SCG whereas it was 72.4 and $77.7 \%$ for CPa in the reed bed and the grassland respectively (Table III). CPUE also differed between trap types. In the pond, $51.3 \%$ of $P$. clarkii individuals were collected in SCG (one-way ANOVA, $F_{6,483}=108.3, p<0.001$ ). When traps $\mathrm{Co}_{1}$ and $\mathrm{Co}_{3}$ were not considered, since crayfish abundance was almost zero in these traps, CPUE was 3.5 to 8.5 times higher in SCG (15.3 crayfish.trap $\left.{ }^{-1} .24 \mathrm{~h}^{-1}\right)$ than in the other trap types (1.8 to 4.4 crayfish.trap ${ }^{-1} .24 \mathrm{~h}^{-1}$ ). The trend in CPUE was fairly similar to that found for catch probability: $\mathrm{SCG}>\mathrm{CPe} \geqslant\left(\mathrm{CN}=\mathrm{Co}_{2}\right)>\mathrm{Co}_{4}>\left(\mathrm{Co}_{1}=\mathrm{Co}_{3}\right)$. The main difference was the position of the $\mathrm{CPe}$ trap along this gradient. $P$. clarkii abundance was higher in $\mathrm{CPe}$ (4.2 crayfish.trap $\left.{ }^{-1} \cdot 24 \mathrm{~h}^{-1}\right)$ than in $\mathrm{Co}_{2}\left(3.5\right.$ crayfish.trap $\left.{ }^{-1} \cdot 24 \mathrm{~h}^{-1}\right)$ whereas catch probability was higher in $\mathrm{Co}_{2}(80.0 \%)$ than in $\mathrm{CPe}(71.4 \%)$. In the reed bed, crayfish CPUE also varied between trap types (one-way ANOVA, $F_{1,59}=14.3, p<0.001$ ). The SCG trap was more efficient than $\mathrm{CPa}$ (6.0 against 2.9 crayfish.trap ${ }^{-1} \cdot 24 \mathrm{~h}^{-1}$, Table III). Results were more marked in the grassland (one-way ANOVA, $F_{1.58}=20.6, p<0.001$ ), since CPUE was three times higher in SCG than in CPa (5.1 against 1.7 crayfish.trap ${ }^{-1} \cdot 24 \mathrm{~h}^{-1}$, Table III). 


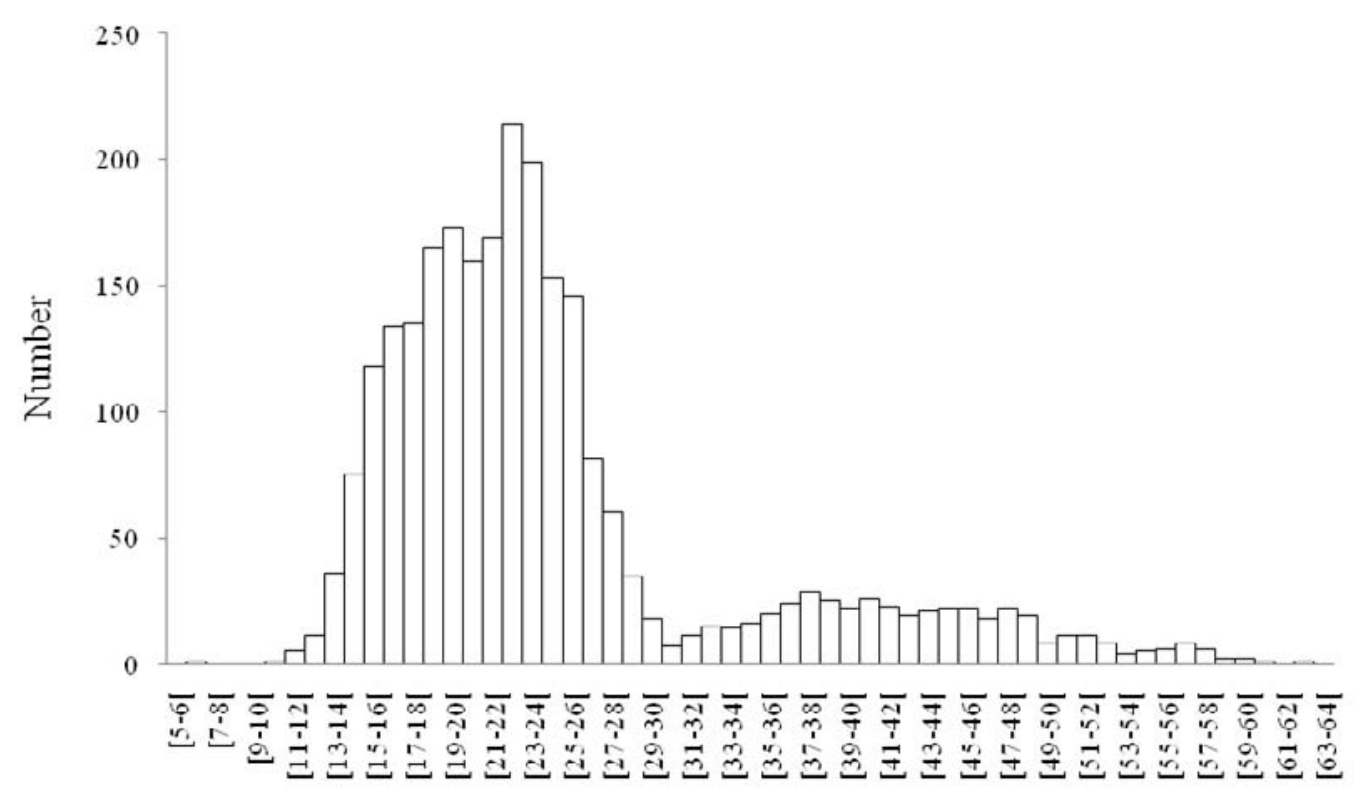

Carapace length $(\mathrm{mm})$

\section{Figure 1}

Carapace length (CT) frequency distribution of P. clarkii captured in the Brière marsh. Interval class is $1 \mathrm{~mm} . \mathrm{N}=2576$ individuals (all trap types and habitats combined).

\section{Figure 1}

Profil des longueurs de céphalothorax (CT) de P. clarkii dans les marais de Brière. L'intervalle de classe est d' $1 \mathrm{~mm} . N=2576$ individus (tous types de pièges et habitats confondus).

\section{> SEX- AND SIZE-SELECTIVITY}

The sex ratio was not statistically different between trap types in each separate habitat (Fisher's exact test, $p>0.05$, Table III), except in one case in the pond where the proportion of females was higher in $\mathrm{CPe}$ (sex ratio $=0.54$ ) than in $\mathrm{CN}$ (sex ratio $=0.44$, Fisher's exact test, $p=0.015)$. Nevertheless all values were not different from a balanced sex ratio.

The application of the Bhattacharya's method to the CL-frequency distribution made it possible to classify crayfish into three size classes: small $(C T \leqslant 30 \mathrm{~mm})$, medium $(30<\mathrm{CT} \leqslant$ $45 \mathrm{~mm}$ ) and large individuals (CT $>45 \mathrm{~mm}$, Figure 1). Small individuals largely dominated the total crayfish captures (82.3\%). Nevertheless, the proportion of small crayfish varied between trap types within the pond (Likelihood-ratio chi-square tests, $p<0.01$, Figure 2), except between SCG and $\mathrm{Co}_{2}$ (Likelihood-ratio chi-square test, $\chi^{2}=3.09$, $\mathrm{df}=2, p=0.21$ ). Small individuals comprised 82.3 to $86.7 \%$ of the total crayfish in these traps, and they were frequently under-represented in the other traps (58.1-71.3\%, Figure 2). Large individuals represented a high proportion of captures in $\mathrm{CN}(26.8 \%)$ compared to the other traps (6.6 to $15.6 \%)$. No significant differences occurred in the proportion of the three size classes between the two trap types in each separate temporarily flooded habitats (Likelihood-ratio chi-square test, $\chi^{2}=0.73$, df $=1, p=0.69$ in the reed bed and $\chi^{2}=2.89$, df $=1, p=0.23$ in the grassland, Figure 2). The proportion of small crayfish varied between 51.1 and $56.6 \%$ respectively in SCG and CPa in the reed bed and between 77.3 and $87.7 \%$ in SCG and CPa in the grassland. In all situations, the resulting CPUE of each crayfish size class were the highest in SCG (one-way ANOVA, $p \leqslant 0.01$, Figure 3). However, no differences occurred in CPUE of large individuals between SCG and CN in the pond and also in CPUE of small individuals between the two trap types in the reed bed. 


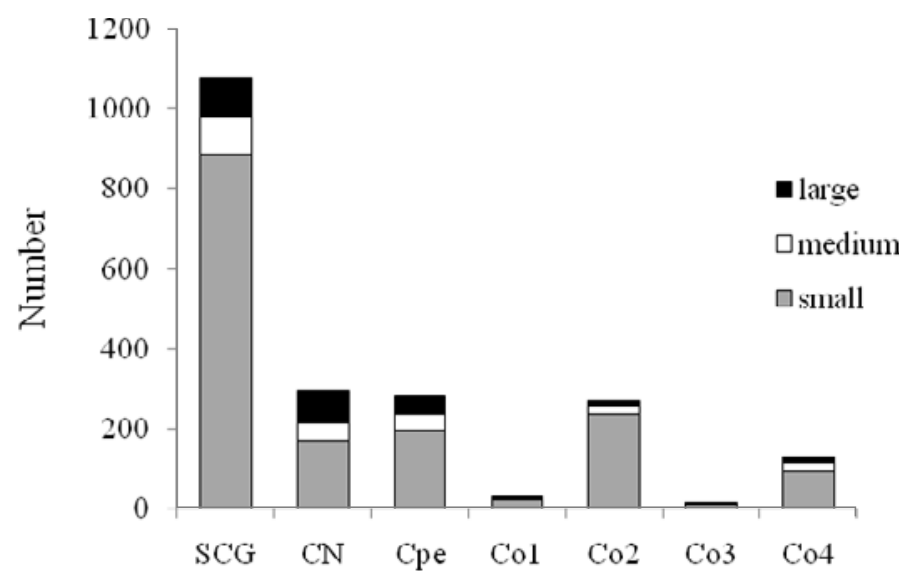

Trap types (within the pond)

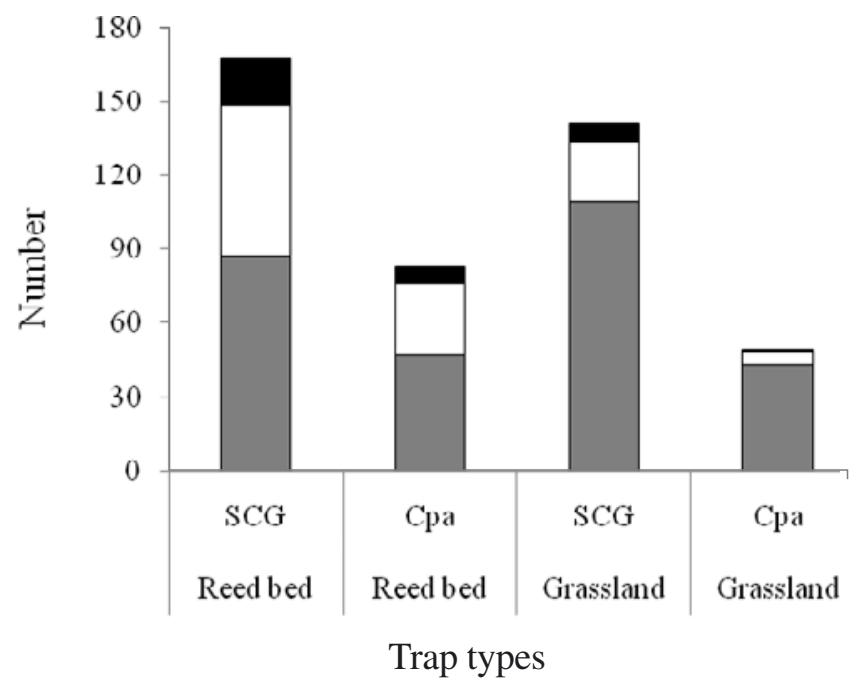

Figure 2

Abundance of three size classes of P. clarkii (small (carapace length, CT $\leqslant 30 \mathrm{~mm}$ ), medium $(30<$ $\mathrm{CT} \leqslant 45 \mathrm{~mm}$ ) and large individuals (CT $>45 \mathrm{~mm}$ )) captured in different traps in three typical temporarily flooded habitats in the Brière marsh (pond, reed bed and grassland). See Table II for details about trap designs.

\section{Figure 2}

Abondance des trois classes de taille de $P$. clarkii (individus petits (longueur de céphalothorax, CT $\leqslant$ $30 \mathrm{~mm}$ ), moyens $(30<\mathrm{CT} \leqslant 45 \mathrm{~mm}$ ) et grands $(\mathrm{CT}>45 \mathrm{~mm})$ ) capturés dans différents pièges et dans trois habitats aquatiques temporaires typiques des marais de Brière (un plan d'eau, une roselière et une prairie inondée). Voir le tableau II pour le détail des pièges et de l'échantillonnage.

\section{DISCUSSION}

This study showed that the use of various trap types resulted in large differences in population structure characteristics of $P$. clarkii whatever the habitat sampled. The most important differences concerned catch probability, CPUE and the proportion of all size classes. Sex ratio was fairly similar and balanced in all situations. Out of the gear tested, semi-cylindrical traps with $5.5 \mathrm{~mm}$ mesh galvanized steel wire (SCG) were the most efficient in capturing $P$. clarkii, a pattern that was consistently observed in all habitats. In the Brière marsh where $P$. clarkii is well-established, catch probability was close to $100 \%$ using SCG instead of $15.7-82.8 \%$ for the other traps and CPUE was 2.1 to 8.5 times higher in SCG than in the other traps in the 

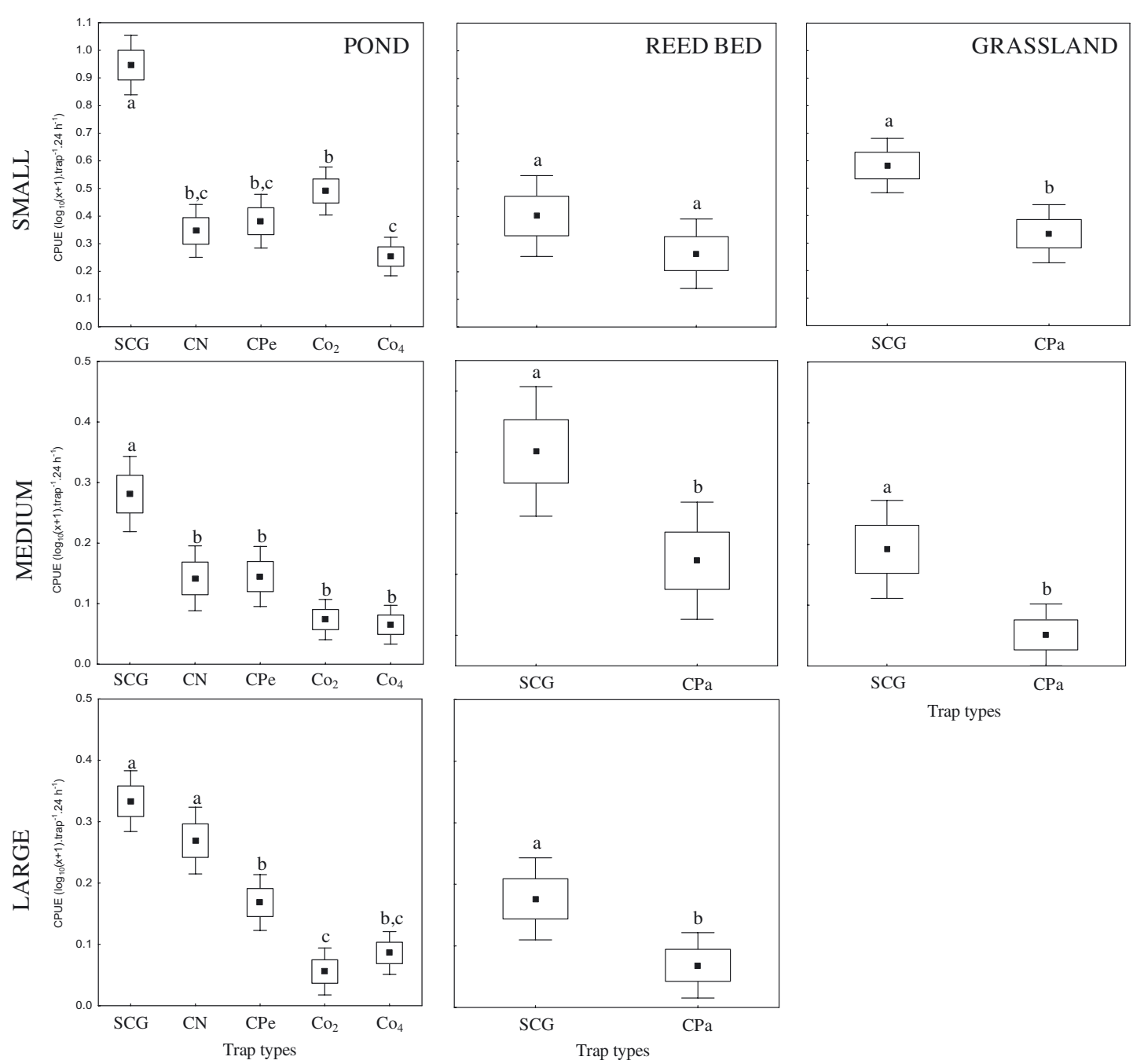

\section{Figure 3}

Capture-per-unit-effort (CPUE, $\log _{10}(x+1) \cdot \operatorname{trap}^{-1} \cdot 24 h^{-1}$ ) of small, medium and large P. clarkii (carapace length, $\mathrm{CT} \leqslant 30 \mathrm{~mm}, 30<\mathrm{CT} \leqslant 45 \mathrm{~mm}$ and $\mathrm{CT}>45 \mathrm{~mm}$ ) captured in different traps in three typical temporarily flooded habitats in the Brière marsh (pond, reed bed and grassland). See Table II for details about trap designs. Results of one-way ANOVAs (trap factor) are indicated. Data with the same letter in each separate graph are not significantly different at $\mathrm{p} \leqslant 0.05$ from pairwise comparisons using a Tukey $\mathrm{HSD}$ test. $\mathrm{Co}_{1}$ and $\mathrm{Co}_{3}$ traps were excluded from analyses in the pond due to few captures. The number of traps with large crayfish was too limited in the grassland to perform an analysis.

\section{Figure 3}

Capture par unité d'effort (CPUE, $\log _{10}(x+1) \cdot$ piège $\left.^{-1} \cdot 24 \mathrm{~h}^{-1}\right)$ en petites, moyennes et grandes écrevisses (longueur de céphalothorax, CT $\leqslant 30 \mathrm{~mm}, 30<\mathrm{CT} \leqslant 45 \mathrm{~mm}$ et CT $>45 \mathrm{~mm}$ ) capturées dans différents pièges et dans trois habitats aquatiques temporaires typiques des marais de Brière (un plan d'eau, une roselière et une prairie inondée). Voir le tableau II pour le détail des pièges et de l'échantillonnage. Les résultats d'ANOVAs à un facteur (effet piège) sont reportés. Pour chaque graphe, les données auxquelles sont associées les mêmes lettres sont significativement non différentes à $p \leqslant 0,05$ d'après les comparaisons par paires réalisées à l'aide du test HSD de Tukey. Les données issues des pièges $\mathrm{Co}_{1}$ et $\mathrm{Co}_{3}$ ont été exclues des analyses pour le plan d'eau en raison d'un trop faible nombre de captures. Aucune analyse n'a été conduite pour les grandes écrevisses dans la prairie inondée en raison d'un trop faible nombre de pièges comportant ces écrevisses. 
three habitats. Our results are in accordance with the findings of Fjälling (1995) who observed that crayfish catches differed significantly with trap design.

In the present study, there were large differences in the size of captured $P$. clarkii between the different trap types. The smallest crayfish were mainly caught in SCG $(52.1$ to $82.3 \%$ of captures depending on habitats). This gear-dependent size selectivity is primarily explained by differences in mesh sizes between traps. High percentages of small individuals in captures were found in traps with small mesh sizes (SCG, $\mathrm{Co}_{2}$ and $\mathrm{CPa}$ ). Large meshed traps underrepresented small individuals in captures (see Table III) and provide a biased picture of the crayfish population structure. Moreover, the design of traps, notably the number of entrances could also influence crayfish captures. For instance, CPUE of small crayfish were markedly higher in SCG than in $\mathrm{Co}_{2}$ in the pond, although the proportion of small individuals in captures was similar in the two traps. Differences in CPUE between trap types (SCG and CPa) were lower in the reed bed and the grassland. These between-trap variations in CPUE for different habitats also suggest that environmental factors such as vegetation cover and water level influence the efficiency of traps. Our results are consistent with similar studies which have used multiple gear types (see also Pfister and Romaire (1983)). Additionally, P. clarkii has special features which can greatly influence its catches in different trap types. It is a bottom dwelling species, and traps with a side entrance are probably more efficient in capturing active crayfish than traps with the entrance at the top. In the latter case, crayfish must climb up the trap to be trapped by the entrance at the top. The use of traps with entrances at the top is motivated by the fact that it will limit the capture of non-target species but the higher this type of trap is, the more difficult it is to catch crayfish. The large proportion of small individuals observed in SCG whatever the habitats (51.1 to $82.3 \%$ ), at this stage of the life cycle of the species, likely reflected the real population structure of $P$. clarkii better (see also Correia, 1995; Anastácio et al., 2009). Indeed, P. clarkii exhibits properties of an $r$-selected species, including particularly high fertility (Gherardi, 2006), and, in the present study, large proportions of small individuals were found only when SCG were used. To be completely sure that SCG provide accurate information about $P$. clarkii population characteristics, additional experiments would be needed such as catching $P$. clarkii in a pond where crayfish have been stocked after having verified that no individual was initially present.

Apart from the efficiency and selectivity of different traps, other factors could influence the use of one trap type or another. We advise against the use of $P$. clarkii population data that has been obtained using multiple trap types, for comparative purposes. Here, we found that one single trap type was adequate for sampling all sizes of $P$. clarkii individuals for all of the studied habitats. Due to its high catch efficiency in the range of habitats studied, SCG could be considered as appropriate catching gear, especially in monitoring projects. For this, additional investigations are needed to establish repeatable sampling procedures that would allow appropriate comparisons of crayfish density, population structure and habitat use by the species in various habitats. The definition of a standardised method using the SCG trap would consist of assessing the accurate catching effort required (notably the number of pieces of gear to deploy in a habitat) to reach a threshold in CPUEs of all size classes of $P$. clarkii in different situations (habitats, crayfish densities. . .).

\section{ACKNOWLEDGEMENTS}

We are indebted to the Parc naturel régional de Brière for logistic support, ONEMA (Office Nationale de l'Eau et des Milieux Aquatiques) and the Région Pays de la Loire for financial support and particularly U. Bierznoj, B. Callard, C. Geslin, B. Hardy and M. Marquet for assistance during field work. We also thank the Direction Départementale de l'Agriculture et de la Forêt, who helped us with the legal transport licence of crayfish, and A. Nys for linguistic improvements. 


\section{REFERENCES}

Alcorlo P., Geiger W. and Otero M., 2008. Reproductive biology and life cycle of the invasive crayfish Procambarus clarkii (Crustacea: Decapoda) in diverse aquatic habitats of South-Western Spain: implications for population control. Fund. Appl. Limnol., 173/3, 197-212.

Anastácio P.M., Leitão A.S., Boavida M.J. and Correia A.M., 2009. Population dynamics of the invasive crayfish (Procambarus clarkii Girard, 1852) at two marshes with differing hydroperiods. Ann. Limnol. - Int. J. Lim., 45, 247-256.

Chiesa S., Scalici M. and Gibertini G., 2006. Occurrence of allochtonous freshwater crayfishes in Latium (Central Italy)? Bull. Fr. Pêche Piscic., 380-381, 883-902.

Correia A.M., 1995. Population dynamics of Procambarus clarkii (Crustacea: Decapoda) in Portugal. Freshwater Crayfish, 8, 276-290.

Correia A.M. and Anastácio P.M., 2008. Shifts in aquatic macroinvertebrate biodiversity associated with the presence and size of an alien crayfish. Ecol. Res., 23, 729-734.

Cucherousset J., Paillisson J.-M., Carpentier A., Eybert M.C. and Olden J.D., 2006. Habitat use of an artificial wetland by the invasive catfish Ameirus melas. Ecol. Freshw. Fish, 15, 589-596.

Cucherousset J., Paillisson J.-M., Carpentier A. and Chapman L.J., 2007. Fish emigration from temporary wetlands during drought: the role of physiological tolerance. Fund. Appl. Limnol., 168, 169-178.

Dörr A.J.M., La Porta G., Pedicillo G. and Lorenzoni M., 2006. Biology of Procambarus clarkii (Girard, 1852) in Lake Trasimeno. Bull. Fr. Pêche Piscic., 380-381, 1155-1168.

Edsman L. and Söderback B., 1999. Standardised sampling methodology for crayfish - The Swedish protocol. Freshwater Crayfish, 12, 705-713.

Fjälling A., 1995. Crayfish traps employed in Swedish fisheries. Freshwater Crayfish, 8, 201-214.

Frutiger A., Borner S., Büsser T., Eggen R., Müller R., Müller S. and Wassmer H.R., 1999. How to control unwanted populations of Procambarus clarkii in Central Europe? Freshwater Crayfish, 12, 714-725.

Geiger W., Alcorlo P., Baltanás A. and Montes, C., 2005. Impact of an introduced Crustacean on the trophic webs of Mediterranean wetlands. Biol. Invasions, 7, 49-73.

Gherardi F., 2006. Crayfish invading Europe: the case study of Procambarus clarkii. Mar. Freshw. Behav. Physiol., 36, 175-191.

Gherardi F., 2007. Understanding the impact of invasive crayfish. In: Gherardi F. (ed.), Biological Invaders in Inland Waters: Profiles, Distribution and Threats, Springer, Dordrecht, 507-542.

Gherardi F., Baldaccini G.N., Ercolini P., Barbaresi S., De Luise G., Mazzoni D. and Mori M., 1999. The situation in Italy. In: Gherardi F. and Holdich D.M. (eds.), Crayfish in Europe as Alien Species. How to Make the Best of a Bad Situation?, A.A. Balkema, Rotterdam, 107-128.

Guerra J.L. and Niño A.E., 1995. Ecology of red swamp crayfish (Procambarus clarkii, Girard) in the Central Meseta of Spain. Freshwater Crayfish, 8, 197-200.

Guttiérrez-Yurrita P.J., Martínez J.M., Bravo-Utrera M.Á., Montes C., Ilhéu M. and Bernardo J.M., 1999. The status of crayfish populations in Spain and Portugal. In: Gherardi F. and Holdich D.M. (eds.), Crayfish in Europe as Alien Species. How to Make the Best of a Bad Situation?, A.A. Balkema, Rotterdam, 161-192.

Hobbs H.H., 1988. Crayfish distribution, adaptive radiation and evolution. In: Holdich D.M. and Lowery R.S (eds.), Freshwater Crayfish: Biology, Management and Exploitation, Croom Helm (Chapman \& Hall), London, 52-82.

Holdich D.M., 2002. Background and functional morphology. In: Holdich D.M. (ed.), Biology of Freshwater Crayfish, Blackwell Science Ltd., London, 3-29.

Huner J.V., 1988. Procambarus in North America and elsewhere. In: Holdich D.M. and Lowery R.S. (eds.), Freshwater Crayfish: Biology, Management and Exploitation, Croom Helm (Chapman \& Hall), London, 239-261.

Huner J.V. and Barr J.E., 1991. Red Swamp Crawfish: Biology and Exploitation, Louisiana Sea Grant College Program, Center for Wetland Resources, Louisiana State University, Baton Rouge.

Huner J.V. and Paret J., 1995. Trap harvest of crawfish (Procambarus spp.) from a South Louisiana commercial pond: effectiveness of different baits and species composition. Freshwater Crayfish, 8, 376-390. 
Ilhéu M., Bernardo J.M. and Fernandes S., 2007. Predation of invasive crayfish on aquatic vertebrates: the effect of Procambarus clarkii on fish assemblages in Mediterranean temporary streams. In: Gherardi F. (ed.), Biological Invaders in Inland Waters: Profiles, Distribution and Threats, Springer, Dordrecht, 543-558.

Ligas A., 2008. Population dynamics of Procambarus clarkii (Girard, 1852) (Decapoda, Astacidea, Camabaridae) from Southern Tuscany (Italy). Crustaceana, 81, 601-609.

Matsuzaki S.S., Usio N., Takamura N. and Washitani I., 2009. Contrasting impacts of invasive engineers on freshwater ecosystems: an experiment and meta-analysis. Oecologia, 158, 673-686.

Pfister V.A. and Romaire R.P., 1983. Catch efficiency and retentive ability of commercial crawfish traps. Aquac. Eng., 2, 101-118.

Qvenild T. and Skurdal J., 1989. Does increased mesh size reduce non-legalized fraction of Astacus astacus in trap catches? Freshwater Crayfish, 7, 277-284.

Rodríguez C.F., Bécares E. and Fernández-Aláez M., 2003. Shift from clear to turbid phase in Lake Chozas (NW Spain) due to the introduction of American red swamp crayfish (Procambarus clarkii). Hydrobiologia, 506, 421-426.

Scalici M. and Gherardi F., 2007. Structure and dynamics of an invasive population of the red swamp crayfish (Procambarus clarkii) in a Mediterranean wetland. Hydrobiologia, 583, 309-319.

Scalici M., Chiesa S., Scuderi S., Celauro D. and Gibertini G., 2010. Population structure and dynamics of Procambarus clarkii (Girard, 1852) in a Mediterranean brackish wetland (Central Italy). Biol. Invasions, 12, 1415-1425.

Westman K., 1991. The crayfish fishery in Finland - its past, present and future. Finn. Fish. Res., 12, 187-216. 